Boletín de la Sociedad Geológica Mexicana

VOLUMEN 67, NÚM. 1, 2015, P. 119-122

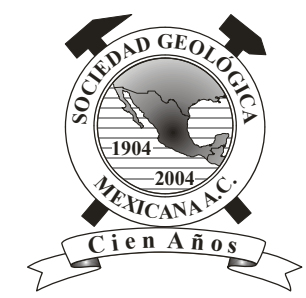

\title{
Short Note Geochronology of Mexican mineral deposits. I: the San Martín polymetallic skarn, Zacatecas
}

\author{
Antoni Camprubí1,*, Eduardo González-Partida ${ }^{2}$, Victor A. Valencia ${ }^{3}$, Fernando Barra ${ }^{4}$ \\ ${ }^{1}$ Instituto de Geología, Universidad Nacional Autónoma de México. Ciudad Universitaria, 04510 México, D.F., Mexico. \\ ${ }^{2}$ Centro de Geociencias, Universidad Nacional Autónoma de México. Boulevard Juriquilla 3001, 76230 Querétaro, Qro., Mexico. \\ ${ }^{3}$ School of the Environment, Washington State University. Pullman, WA 99164-2812, U.S.A. \\ ${ }^{4}$ Departamento de Geología, Universidad de Chile. Plaza Ercilla \#803, Casilla 13518 Correo 21, Santiago, Chile. \\ *Corresponding author: camprubitaga@gmail.com
}

\begin{abstract}
The $\mathrm{Zn}-\mathrm{Pb}-\mathrm{Cu}(-\mathrm{Ag} \pm \mathrm{Au}) \mathrm{San}$ Martín deposit in northwestern Zacatecas is one of the most economically important and biggest skarns in Mexico. Mineral associations in this deposit belong to the sulfide skarn type (with rather "classical" prograde and retrograde zones) and contain peripheral subepithermal to epithermal veins. Re-Os ages were obtained for two molybdenite samples from deep $\mathrm{Cu}-\mathrm{Zn}-\mathrm{Pb} \pm \mathrm{Mo} \pm \mathrm{Bi} \pm \mathrm{Ag}$ retrograde mineralization in these deposits, of $43.7 \pm 0.3$ and $44.0 \pm 0.2 \mathrm{Ma}$, which correspond essentially to the same age. These are 1 to 3 Myr younger than preexisting K-Ar ages for the granitic stock that generated these mineral deposits. Prograde mineral associations are hereby interpreted to have been directly associated with this intrusion. Therefore, we may calculate a simple decrease rate in temperatures of hydrothermal fluids between $\sim 100^{\circ}$ and $>300^{\circ} \mathrm{C}$ per million years from prograde to retrograde skarn associations. Subepithermal and epithermal veins, however, remain undated.
\end{abstract}

Keywords: San Martín, Zacatecas, Mexico, sulfide skarn deposits, polymetallic ores, Re-Os, molybdenite.

\section{Resumen}

El depósito de $\mathrm{Zn}-\mathrm{Pb}-\mathrm{Cu}(-\mathrm{Ag} \pm \mathrm{Au})$ de San Martín en el noroeste de Zacatecas es uno de los skarns de mayor importancia económica y tamaño en México. Las asociaciones minerales de este depósito pertenecen a la tipología de los skarns de sulfuros (con zonaciones prógradas y retrógradas "clásicas") y contiene en su periferia vetas subepitermales a epitermales. Se obtuvieron edades Re-Os en este depósito para dos muestras de molibdenita de mineralizaciones retrógradas de $C u$ - $\mathrm{Zn}-\mathrm{Pb} \pm \mathrm{Mo} \pm \mathrm{Bi} \pm \mathrm{Ag}$, en $43.7 \pm 0.3$ y $44.0 \pm 0.2 \mathrm{Ma}$, que corresponden esencialmente a la misma edad. Éstas son de 1 a 3 millones de años más recientes que las edades K-Ar preexistentes del stock granítico responsable de la formación de estos depósitos. Las asociaciones minerales prógradas se interpretan en este trabajo como directamente asociadas a dicho intrusivo. Por lo tanto, puede calcularse una simple tasa de descenso de temperaturas para los fluidos hidrotermales de entre $\sim 100^{\circ} y>300^{\circ} \mathrm{C}$ por millón de años, desde las asociaciones prógradas, de skarn, a las retrógradas. Las vetas subepitermales y epitermales, sin embargo, todavia carecen de determinaciones geocronológicas.

Palabras clave: San Martín, Zacatecas, México, skarn de sulfuros, menas polimetálicas, Re-Os, molibdenita. 


\section{Introduction}

The San Martín mining district (northwestern Zacatecas, central-northern Mexico) is composed of $\mathrm{Zn}-\mathrm{Pb}-\mathrm{Cu}(-$ $\mathrm{Ag} \pm \mathrm{Au})$ sulfide skarn deposits and Ag-rich epithermal to subepithermal deposits. It contains average mill-head grades of $450 \mathrm{ppm} \mathrm{Ag}$ and $0.5 \mathrm{ppm} \mathrm{Au}$. At present, large mantos are mined, with average grades of $5 \% \mathrm{Zn}, 1 \% \mathrm{Cu}, 0.5 \%$ $\mathrm{Pb}$, and $150 \mathrm{ppm} \mathrm{Ag}$. Total ore reserves, including mined ores, are estimated at over $100 \mathrm{Mt}$, thus indicating that San Martín is a world-class mining district. This deposit used to be considered as the biggest of its kind in Mexico until the discovery of the giant Peñasquito deposit in the Mazapil district, in northeastern Zacatecas.

Previous work in the area comprised mineralogical and geochemical (Aranda-Gómez, 1978; Rubin and Kyle, 1988), structural (Starling et al., 1997), and fluid inclusion studies (González-Partida and Camprubí, 2006). The skarn deposits comprise four prograde zones (Aranda-Gómez, 1978) from the granitic stock outwards: (1) garnet - clinopyroxene zone \pm hedenbergite zone, (2) tremolite - garnet - wollastonite zone, (3) tremolite - actinolite - marble zone, and (4) saccharoidal quartz - potassium feldspar and stockwork zones. The retrograde associations include (Aranda-Gómez, 1978): (a) propylitic alteration, with epidote, vesuvianite, chlorite, calcite and minor quartz, (b) silicification adjacent to epithermal veins, and (c) calcite veinlets and pervasive carbonatization, with minor chalcedony, that represents the latest hydrothermal event in the district. The deposition of ore minerals occurred from the beginning of retrogradation and continued with the formation of subepithermal to epithermal veins (e.g., the Noria de San Pantaleón vein).

The sole existing age determination related to the sulfide skarn mineralization is a $\mathrm{K}-\mathrm{Ar}$ age for biotite from the Cerro de la Gloria granitic stock, at 46.2 $\pm 1 \mathrm{Ma}$ (Damon et al., 1983). This stock developed endoskarn and exoskarn mineralization, with an external aureole of pervasive carbonatization that extends over $1 \mathrm{~km}$ away from the contact with the host Cretaceous carbonate rocks (Cuesta del Cura Formation; Figure 1), which includes peripheral intermediate sulfidation subepithermal to epithermal veins (Camprubí and Albinson, 2006, 2007; González-Partida and Camprubí, 2006). The San Martín sulfide skarn deposit was therefore formed during the metallogenic epoch that is most prospective for skarn deposits in the region, during the Eocene (epoch 4, Figure 13 in Camprubí, 2013). Such a metallogenic feature is due to the eastward progression of magmatism in the Sierra Madre Occidental silicic large igneous province (SLIP) into the carbonate basins in central Mexico and along the long-lived, NW-SE striking San Luis-Tepehuanes Fault Zone, which constitutes most of the southern border of the Mesa Central (or Mexican Altiplano; Nieto-Samaniego et al., 2005, 2007). The stock that generated the skarn deposits is controlled by two WNW-ESE striking sinistral transtensional fault zones in the pre-Laramide basement, located north and south of the intrusion that were reactivated during the Laramide orogeny (Starling et al., 1997). The San Luis-Tepehuanes Fault Zone determined a trend in the distribution of ore deposits that constitutes the strip of land in which these are the most abundant in Mexico, and these formed between the Late Cretaceous and the Oligocene (Camprubí, 2013).

In this paper, we report the first age determinations of any of the metallic mineral assemblages of the San Martín deposit, and essay a possible rate of overall cooling between prograde and retrograde mineralization.

\section{Methods and results}

Two molybdenite samples for Re-Os dating were obtained from different locations of deep retrograde mineral associations. Both samples were digested using the Carius tube method (Shirey and Walker, 1995), and were analyzed following the procedure described by Barra et al. (2003, 2005). About 50 to $70 \mathrm{mg}$ of pure molybdenite was loaded in the Carius tube with Re and Os spikes, and then dissolved in inverse aqua regia by heating in an oven at 220 ${ }^{\circ} \mathrm{C}$ for $\sim 12 \mathrm{~h}$. After homogenization of the solution, Re and Os were separated using a distillation technique (Nägler and Frei, 1997), in which Os was collected into cold HBr. Later, the dried Os was purified using the microdistillation technique of Birck et al. (1997), while Re was purified using AG1-X8 anion exchange resin. Along with Ba salts to enhance ionization, $\mathrm{Re}$ and $\mathrm{Os}$ were loaded on $\mathrm{Ni}$ and Pt filaments, respectively. Measurements were carried out by negative thermal ion mass spectrometer (NTIMS) at the University of Arizona.

The molybdenite samples thus dated yielded Re-Os ages of $43.7 \pm 0.3$ and $44.0 \pm 0.2 \mathrm{Ma}$ and are presented in Table 1 .

\section{Discussion and conclusions}

Two Re-Os ages were obtained in this study for molybdenite from deep retrograde metallic mineral associations of the San Martín sulfide skarn deposits in Zacatecas, of $43.7 \pm 0.3$ and $44.0 \pm 0.2 \mathrm{Ma}$. Such ages are, statistically, the same. These, as expected, are younger than the available K-Ar age for the Cerro de la Gloria granitic stock (46.2 $\pm 1 \mathrm{Ma}$; Damon et al., 1983), which is associated with these skarn deposits. Then, the time span between the intrusion of the granitic stock — and the subsequent prograde mineralization - and the retrograde mineralization would vary from 1 to $3 \mathrm{Myr}$, which is reasonable for the thermal peak at similar systems (e.g., Anczkiewicz et al., 2014). This implies a decrease in temperature from $645^{\circ} \mathrm{C}$, as the maximum temperature in the prograde skarn zone, down to $\sim 300^{\circ} \mathrm{C}$, as the minimum temperature in the retrograde skarn zone, and even down to $\sim 100^{\circ} \mathrm{C}$ in subepithermal and epithermal veins (after the temperatures of homogenization in fluid inclusions obtained by González-Partida and 

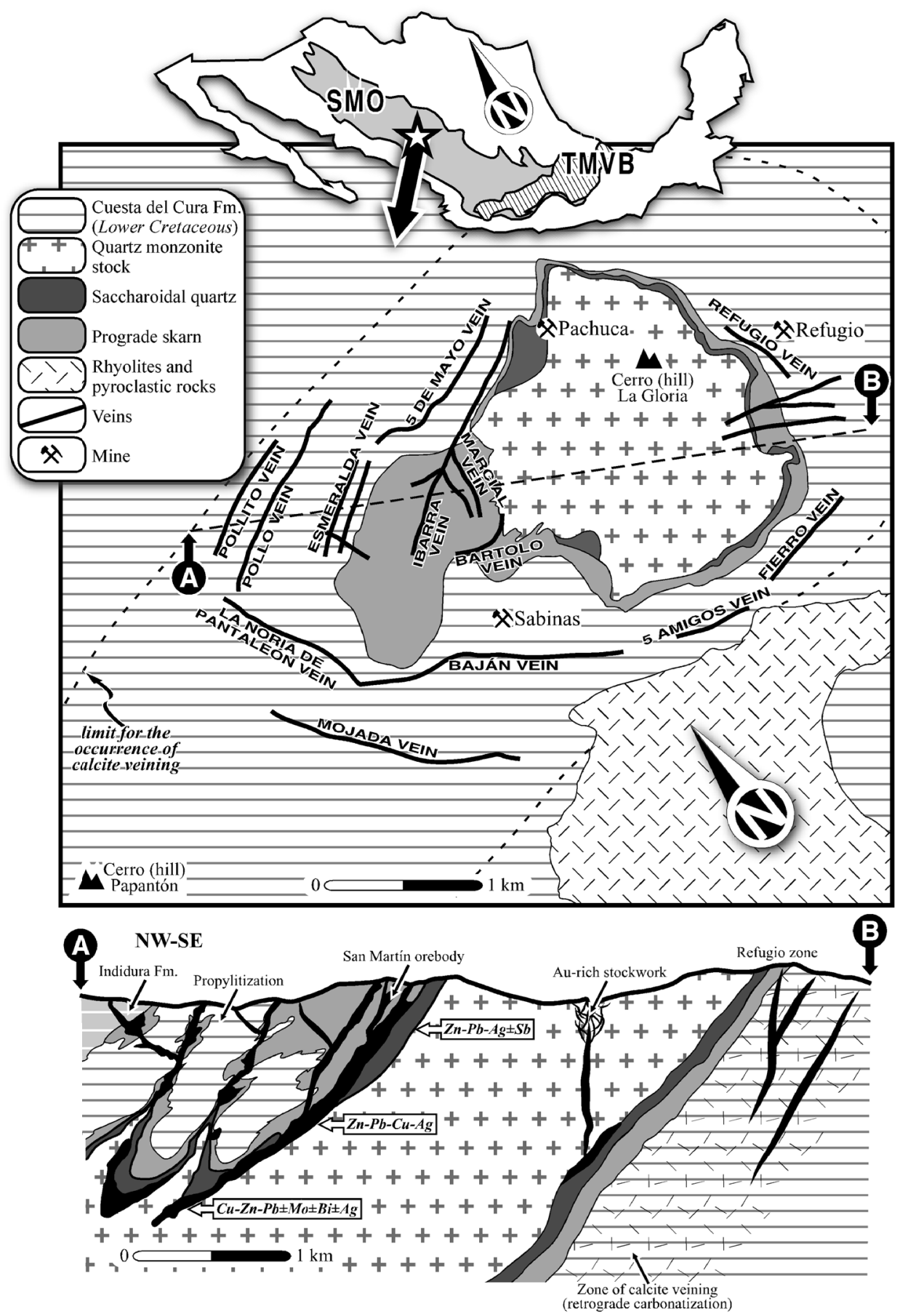

Figure 1. Above: Location and geological map of the San Martín district, northwestern Zacatecas state, Mexico, taken from González-Partida and Camprubí (2006), and modified from Rubin and Kyle (1988) and Starling et al. (1997). Below: Geologic cross section featuring the main ore bodies in the district, taken from González-Partida and Camprubí (2006), and modified from Starling et al. (1997). The dated molybdenite samples were obtained from the deep $\mathrm{Cu}-\mathrm{Zn}-\mathrm{Pb} \pm \mathrm{Mo} \pm \mathrm{Bi} \pm \mathrm{Ag}$ mineralization along the contact between the Cerro de la Gloria granitic stock and the Cuesta del Cura Formation. Key: SMO = Sierra Madre Occidental, TMVB = Trans-Mexican Volcanic Belt.

Table 1. Re-Os ages for molybdenite samples of the San Martín sulfide retrograde skarn associations, Zacatecas.

\begin{tabular}{|c|c|c|c|c|c|c|c|c|}
\hline Sample & Mineral & Weight (g) & Total Re (ppm) & ${ }^{187} \operatorname{Re}(\mathrm{ppm})$ & ${ }^{187}$ Os (ppm) & Age (Ma) & & $2-\sigma$ \\
\hline SM-moly1 & Molybdenite & 0.104 & 7.81 & 4.89 & 3.56 & 43.7 & \pm & 0.3 \\
\hline SM-moly2 & Molybdenite & 0.083 & 15.24 & 9.54 & 7 & 44 & \pm & 0.2 \\
\hline
\end{tabular}


Camprubí, 2006). Thus, the decrease rate in temperatures of hydrothermal fluids would have varied between $\sim 100^{\circ}$ and $>300{ }^{\circ} \mathrm{C}$ per million years (Figure 2).

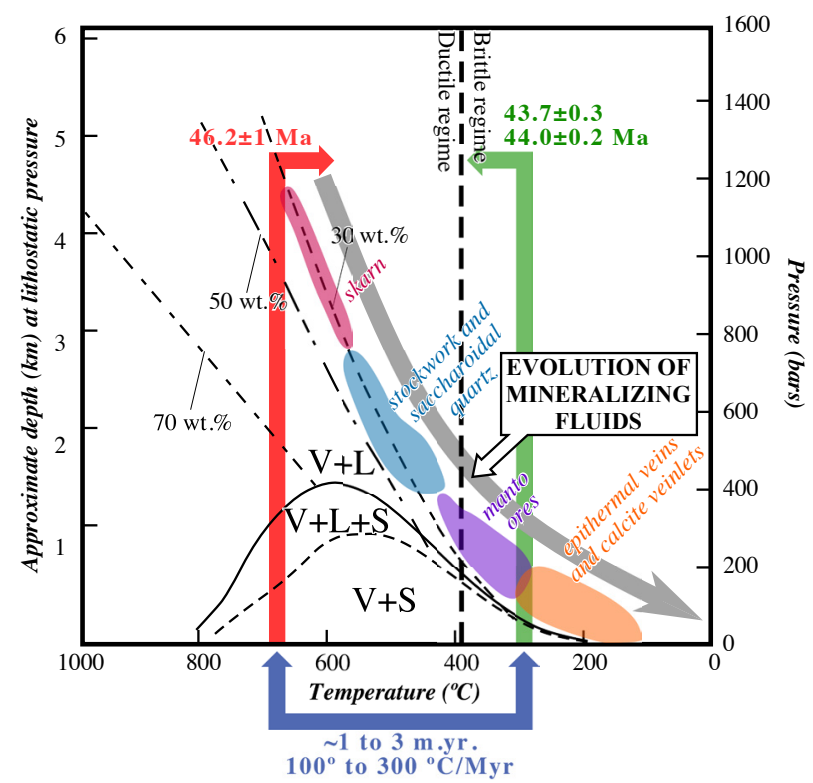

Figure 2. Correlation diagram between temperature and depth of mineralizing fluids in the San Martín district, modified from the fluid inclusion study by González-Partida and Camprubí (2006), showing the phase relations in the system water- $\mathrm{NaCl}$, at lithostatic pressure, and key isosalinity lines (30, 50 y 70 wt. $\% \mathrm{NaCl}$ equiv), adapted from Fournier (1999). It includes the age determinations for this study, as associated to the retrograde mineralization (in green) and the ages for the Cerro de la Gloria granitic stock, as part of the prograde mineralization (in red) by Damon et al. (1983). Key: L = liquid, $\mathrm{S}=$ solid (halite), $\mathrm{V}=$ vapor.

\section{Acknowledgements}

This study was financed by means of CONACYT grant number 155662. The authors wish to thank all the technical staff at the University of Arizona in Tucson for providing assistance to perform the geochronology studies. The age determinations in this study were first mentioned by Camprubí (2013). Formal reviews were conducted by José María González Jiménez and Yoann Gréau, whose comments helped to improve this paper.

\section{References}

Anczkiewicz, R., Chakraborty, S., Dasgupta, S., Mukhopadhyay, D., Koltonik, K., 2014, Timing, duration and inversion of prograde Barrovian metamorphism constrained by high resolution Lu-Hf garnet dating: A case study from the Sikkim Himalaya, NE India: Earth and Planetary Science Letters, 407, 70-81.
Aranda-Gómez, J.J., 1978, Metamorphism, mineral zoning, and paragenesis in the San Martín mine, Zacatecas, Mexico: Unpublished MSc thesis, Colorado School Mines, Golden CO, USA, 90 p.

Barra, F., Ruiz, J., Mathur, R., Titley, S.R., 2003, A Re-Os study on sulphide minerals from the Bagdad porphyry $\mathrm{Cu}-\mathrm{Mo}$ deposit, northern Arizona, USA: Mineralium Deposita, 38, 585-596.

Barra, F., Ruiz, J., Valencia, V.A., Ochoa-Landín, L., Chesley, J.T., Zürcher, L., 2005, Laramide porphyry Cu-Mo mineralization in northern Mexico: age constraints from Re-Os geochronology in molybdenite: Economic Geology, 100, 1605-1616.

Birck, J.L., Roy Barman, M., Capmas, F., 1997, Re-Os measurements at the femtomole level in natural samples: Geostandards Newsletter, 20, 19-27.

Camprubí, A., 2013, Tectonic and metallogenic history of Mexico, in Colpron, M., Bissig, T., Rusk, B.G., Thompson, J.F.H. (eds.), Tectonics, metallogeny, and discovery: the North American Cordillera and similar accretionary settings: Society of Economic Geologists, Special Publication, 17, 201-243.

Camprubí, A., Albinson, T., 2006, Depósitos epitermales en México: actualización de su conocimiento y reclasificación empírica: Boletín de la Sociedad Geológica Mexicana, 58(1), 27-81.

Camprubí, A., Albinson, T., 2007, Epithermal deposits in México - an update of current knowledge, and an empirical reclassification, in Alaniz-Álvarez, S.A., Nieto-Samaniego, A.F. (eds.), Geology of México: Celebrating the Centenary of the Geological Society of México: The Geological Society of America Special Paper, 422, 377-415.

Damon, P.E., Shafiqullah, M., Clark, K.F., 1983, Geochronology of the porphyry copper deposits and related mineralization of Mexico: Canadian Journal of Earth Sciences, 20, 1052-1071.

Fournier, R.O., 1999, Hydrothermal processes related to movement of fluid from plastic into brittle rock in the magmatic-epithermal environment: Economic Geology, 94, 1193-1221.

González-Partida, E., Camprubí, A., 2006, Evolution of mineralizing fluids in the $\mathrm{Zn}-\mathrm{Pb}-\mathrm{Cu}(-\mathrm{Ag} \pm \mathrm{Au})$ skarn and epithermal deposits of the world-class San Martín district, Zacatecas, Mexico: Journal of Geochemical Exploration, 89(1-3), 138-142.

Nägler, T.F., Frei, R., 1997, Plug in plug osmium distillation: Schweizerische Mineralogische und Petrographische Mitteilungen, 77, 123-127.

Nieto-Samaniego, Á.F., Alaniz-Álvarez, S.A., Camprubí, A., 2005, La Mesa Central de México: estratigrafía, estructura y evolución tectónica cenozoica: Boletín de la Sociedad Geológica Mexicana, 57(3), 285-318.

Nieto-Samaniego, Á.F., Alaniz-Álvarez, S.A., Camprubí, A., 2007, The Central Mesa of México: stratigraphy, structure and tectonic evolution during the Cenozoic, in Alaniz-Álvarez, S.A., NietoSamaniego, A.F. (eds.), Geology of México: Celebrating the Centenary of the Geological Society of México, The Geological Society of America Special Paper, 422, 41-70.

Rubin, J.N., Kyle, J.R., 1988, Mineralogy and geochemistry of the San Martín skarn deposit, Zacatecas, Mexico: Economic Geology 83, 1782-1792.

Shirey, S., Walker, R., 1995, Carius tube digestion for low-blank rheniumosmium analysis: Analytical Chemistry, 67, 2136-2141.

Starling, T., Uribe, J., Maldonado, D., 1997, Nuevos conceptos que definen los controles estructurales y la evolución del yacimiento de San Martín, Zacatecas, México: Trabajos técnicos XXII Convención Nacional Asociación de Ingenieros de Minas, Metalurgistas y Geólogos de México, A.C., Acapulco, Guerrero, 1, 327-338.

Manuscript received: Febraury 24, 2015

Corrected manuscript received: March 23, 2015

Manuscript accepted: March 25, 2015 